\title{
Peningkatan Life Skills Melalui Pembelajaran IPA Pendekatan Scientific Pada Siswa MI
}

\author{
Ummu Khairiyah \\ Program Studi Pendidikan Guru Madrasah Ibtidaiyah \\ Universitas Islam Lamongan \\ e-mail : ummukhairiyah@unisla.ac.id
}

\begin{abstract}
Abstrak : This study is aimed at improving Life Skills through the application of scientific approach. The stages of this study is to analyze the problems in school, develop scientific approach-based learning tools, and use learning tools. The subjects of this study were 30 MI students on the environmental pollution subject matter. In this study, data collection techniques used qualitative and quantitative descriptive analysis. The results showed that life skills consisting of thinking skills, academic skills and social skills increased after being given an activity through science teaching based on a scientific approach.
\end{abstract}

Keywords: life skills, scientific approach, learning tools.

\section{A. Pendahuluan}

Pendidikan merupakan cara operasional yang dilakukan untuk meningkatkan kualitas hidup manusia melalui proses pembelajaran. Program pembelajaran yang baik akan menghasilkan efek berantai pada kemampuan peserta didik untuk belajar secara terus menerus melalui lingkungannya (alam dan social) sebagai sumber belajar yang tak terbatas (Anwar, 2006). Melalui pendidikan, akan membekali peserta didik dengan knowledge (pengetahuan) dan skills (keterampilan). Dengan menguasai keduanya, harapannya peserta didik dapat menyesuaikan diri dan diterima oleh masyarakat untuk menyelesaikan berbagai macam persoalan yang muncul di masyarakat.

Berbagai persoalan yang dihadapi masyarakat salah satunya yakni masih tingginya tingkat kesenjangan ekonomi dimana masyarakat kalangan bawah lebih dominan daripada kalangan atas. Selain itu masih tinggi pula tingkat pengangguran dan krimilitas dikarenakan jumlah angkatan kerja lebih besar disbanding kesempatan kerja. Oleh karena itu, melalui pendidikan diharapkan akan muncul solusi untuk mengatasi persoalan yang terjadi di masyarakat. Berdasarkan hasil penelitian Litbang Jawa Timur (Litbang Jawa Timur, 2005) dalam menjawab perihal masyarakat miskin, alternative pendidikan yang memberdayakan masyarakat miskin adalah kecakapan hidup (Life skills). Life skills pada diri seseorang perlu dilatih, karena manfaat life skills bagi siswa adalah sebagai bekal dalam menghadapi dan memecahkan 

problem hidup dan kehidupan, baik sebagai pribadi yang mandiri, warga masyarakat, maupun sebagai warga Negara (Tim Education, 2002).

Life skills merupakan pendidikan yang orientasi dasarnya membekali keterampilan siswa yang menyangkut aspek pengetahuan, sikap yang didalamnya termasuk fisik dan mental, serta kecakapan kejuruan yang berkaitan dengan pengembangan peserta didik sehingga mampu menghadapi tuntutan dan tantangan hidup dalam kehidupan.

Mata pelajaran IPA dikembangkan melalui kemampuan berpikir analitis, induktif, dan deduktif untuk penyelesaian masalah yang berkaitan dengan peristiwa alam sekitar (Lampiran permendiknas No 22 tahun 2006). IPA menyediakan pengalaman belajar untuk memahami konsep melalui kegiatan mengamati, mengajukan hipotesis, menggunakan alat dan bahan secara baik dan benar dengan selalu mempertimbangkan keamanan dan keselamatan kerja, mengajukan pertanyaan, menafsirkan data, serta mengkomunikasikan hasil temuan secara lisan atau tertulis, menggali dan memilah informasi faktual yang relevan untuk memecahkan masalah. UNESCO mencanangkan 4 pilar pendidikan yang jika diterapkan nantinya akan mampu membekali peserta didik dengan kecakapan hidup diantaranya learning to know, learning to do, learning to be, dan learning to live together.

Untuk mendukung pencapaian empat pilar tersebut maka dibutuhkan pendekatan pembelajaran yang mampu mengembangkan kecakapan hidup peserta didik dengan berperan aktif dalam pembelajaran. Salah satu pendekatan pengajaran yang mampu melibatkan siswa berperan aktif adalah pendekatan scientific. Melalui pendekatan scientific selain menjadikan siswa lebih aktif dalam mengkonstruksi pembelajaran dan keterampilan, juga dapat mendorong siswa untuk melakukan penyelidikan guna menemukan fakta-fakta dari suatu fenomena atau kejadian (Kemendikbud, 2013). Pendekatan scientific mampu menyediakan berbagai pengalaman belajar untuk memahami konsep dan proses sains meliputi keterampilan mengamati, mengajukan hipotesis, mengajukan pertanyaan, menggolongkan dan menafsirkan data, mengkomunikasikan hasil data yang diperoleh, menggali dan memilah informasi yang relevan untuk digunakan dalam memecahkan masalah dalam kehidupan sehari-hari yang dekat dengan siswa (Kemendikbud, 2013).

Berdasarkan hasil observasi di salah satu MI di Surabaya, dalam proses pembelajaran IPA masih teacher centered dan cenderung textbook oriented. Tatap muka untuk kegiatan praktikum masih sangat minim, biasanya hanya dilakukan 2 kali dalam satu semester. Selebihnya pembelajaran dilakukan dengan ceramah, padahal banyak materi IPA yang membutuhkan kegiatan praktikum atau melakukan pengamatan. Dapat dikatakan bahwa masih jarang dilakukan kegiatan eksperimen dan praktikum sehingga 
siswa kurang terampil didalam menyelesaikan masalah, akibatnya kemampuan life skills yang dimiliki siswa kurang.

\section{B. Metode}

Penelitian ini menggunakan pendekatan kualitatif dan kuantitatif. Subyek penelitian ini dilaksanakan pada 30 siswa MI pada materi pencemaran lingkungan. Alur dari penelitian ini terdiri dari 4 tahap yakni Define, Design, Develop, dan Disseminate. Pada tahap pendefinisian (Define) dilakukan:

1. Analisis kebutuhan dengan tujuan mengidentifikasi dan menetapkan masalah mendasar yang akan diangkat,

2. Analisis kurikulum, untuk mengidentifikasi keterampilan apa saja yang harus dimiliki berdasarkan Kompetensi inti (KI) dan Kompetensi Dasar (KD),

3. Analisis siswa, untuk mengetahui karakteristik siswa mulai dari umur, keterampilan psikomotor, keterampilan sosial, motivasi terhadap mata pelajaran serta kemampuan akademik siswa,

4. Analisis Kompetensi Dasar bertujuan untuk mengidentifikasi materi pokok yang menjadi pembahasan dan harus dicapai siswa setelah pembelajaran selesai,

5. Analisis Tugas, Analisis ini merupakan tatacara dalam bentuk garis-garis besar yang menganalisis pengalaman belajar apa yang akan diberikan pada siswa dan keterampilan apa yang akan dipelajari siswa (Kemp, J. E., M. G. R., and Ross, 1994),

6. Analisis konsep, bertujuan untuk mengidentifikasi konsep-konsep utama yang akan diajarkan pada materi pencemaran lingkungan.

Tahap selanjutnya adalah perancangan (Design). Tahap ini bertujuan untuk mendesain atau merancang perangkat pembelajaran. Pada tahap ini dilakukan:

1. tahap penyusunan tes, Penyusunan tes didasarkan pada tujuan pembelajaran, indikator, materi yang diajarkan dalam spesifikasi tujuan pembelajaran. Ada dua tes yang dikembangkan, yaitu tes hasil belajar kognitif dan tes kemampuan life skills. Tes hasil belajar kognitif digunakan untuk mengetahui kemampuan kognitif siswa, sedangkan tes kemampuan life skills digunakan untuk mengukur life skills siswa

2. Tahap pemilihan media, Pada tahap ini dilakukan untuk menentukan media yang tepat dalam penyajian materi pembelajaran yang disesuaikan dengan karakteristik siswa dan fasilitas yang tersedia disekolah.

3. Desain awal pembelajaran. Desain awal adalah penyusunan perangkat pembelajaran pada tahap draf. Penyusunan perangkat pembelajaran digunakan untuk mempermudah dan memperlancar kegiatan belajar mengajar sesuai dengan tujuan yang telah ditetapkan. 
Tahap yang ketiga pengembangan (Develop) dimana perangkat pembelajaran yang telah dibuat selanjutnya di validasi dan dan direvisi serta di uji cobakan. Desain uji coba menggunakan rancangan One Group Pretest-Post test Design (Tuckman, 1986).

Analisis data pada penelitian ini berupa analisis kualitatif dan kuantitatif. Analisis kualitatif menggunakan lembar instrumen validasi dan lembar angket keterbacaan perangkat, sedangkan analisis kuantitatif yakni menganalisis kemampuan life skills. Kemampuan life skills diperoleh dari hasil tes tulis untuk academic dan thinking skills sedangkan social skills dari hasil pengamatan. Hasil yang diperoleh kemudian dianalisis untuk mengetahui ketuntasan siswa secara individu dan klasikal.

\section{Hasil dan Pembahasan}

Kegiatan penelitian yang telah dilaksanakan pada tahap awal, peneliti mengembangkan perangkat pembelajaran dengan pendekatan scientific untuk melatihkan life skills siswa. Selanjutnya perangkat yang telah jadi di validasi oleh validator kemudian di uji cobakan ketika hasil validasi menunjukkan bahwa perangkat pembelajaran layak digunakan. Berdasarkan hasil analisis data, diperoleh hasil sebagai berikut:

\section{Kemampuan Kecakapan Hidup}

Life skills merupakan sejumlah kecakapan yang perlu dimiliki oleh siswa. Dalam penelitian ini life skills yang diamati adalah thinking skills, academic skills, dan social skills. Thinking skills meliputi: (1) menggali informasi, (2) mengolah informasi, dan (pengambilan keputusan). Sementara academic skills meliputi: (1) merumuskan masalah, (2) merumuskan hipotesis, (3) menentukan variabel, (4) membuat rancangan percobaan, (5) menyajikan data dalam tabel, (6) menganalisis data, dan (7) membuat kesimpulan. Sedangkan social skills meliputi: (1) mengajukan pertanyaan, (2) menjawab pertanyaan, (3) mengemukakan pendapat, (4) menanggapi pendapat, dan (5) presentasi lisan.

\section{Thinking Skills}

Penilaian keterampilan thinking skills diperoleh melalui hasil pengamatan dan tes hasil belajar. Hasil pengamatan dilakukan selama 3 kali pertemuan. Berdasarkan hasil pengamatan diperoleh nilai optimum siswa untuk masing-masing kompetensi pada keterampilan thinking skills. Keterampilan thinking skills yang dinilai meliputi 1) keterampilan menggali informasi, 2) keterampilan mengolah informasi, dan 3) keterampilan pengambilan keputusan. Foong May dalam penelitiannya menegaskan apabila siswa dilatihkan keterampilan berfikir (thinking skills), maka mereka nantinya akan dapat membantu memecahkan masalah dalam kehidupan nyata (Foong May, 2014). 


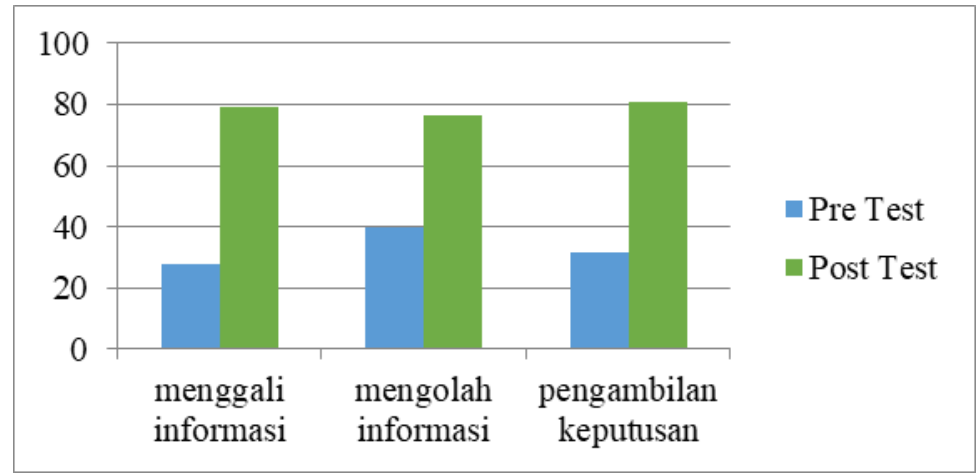

Gambar 1.1 Diagram Nilai Kemampuan Thinking Skills

Sedangkan penilaian kemampuan thinking skills melalui tes hasil belajar.dilakukan dengan mengerjakan soal essay. Diperoleh hasil seperti pada Gambar 2 berikut:

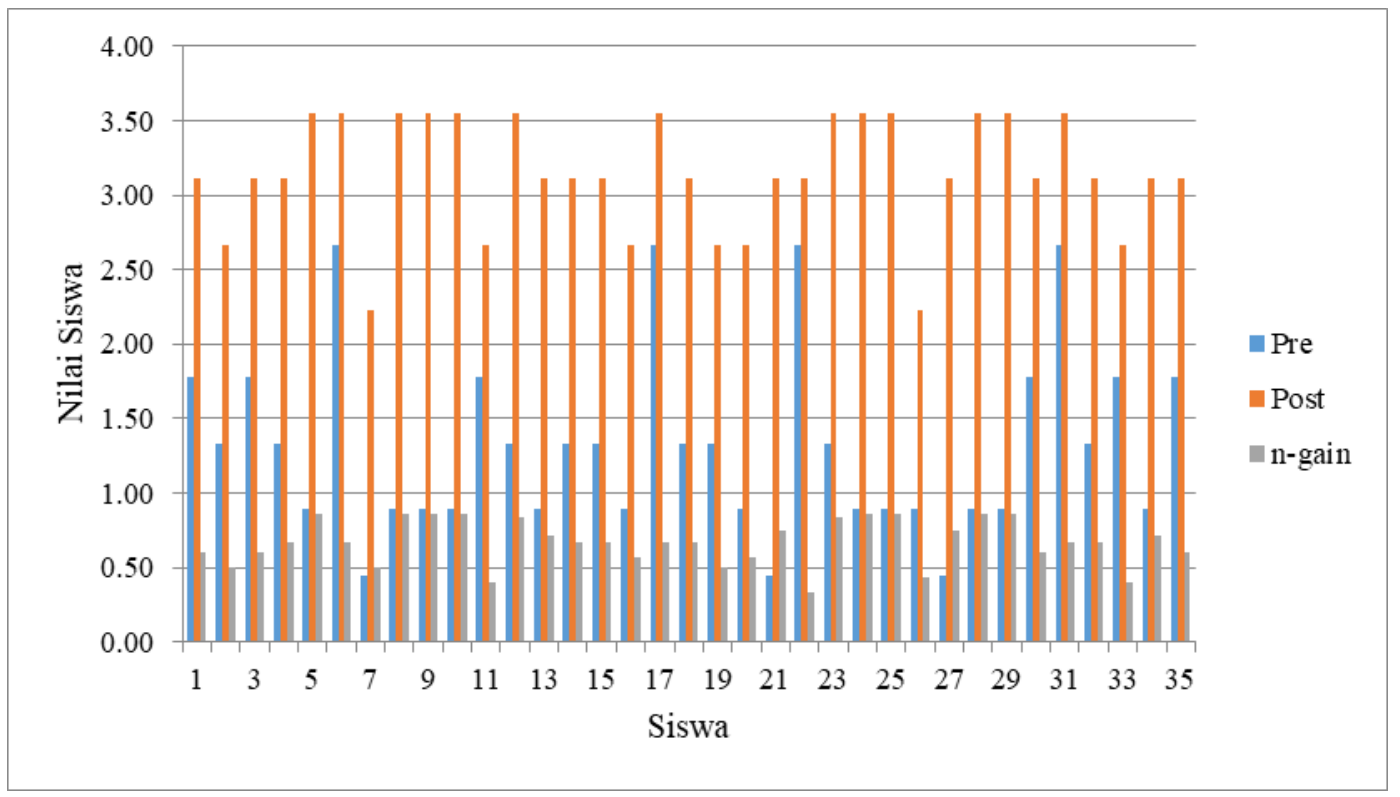

Gambar 1.2 Diagram Tes Hasil Belajar (Thinking Skills)

Kompetensi menggali informasi tercapai apabila peserta didik mampu mengobservasi fakta dan peristiwa sederhana yang menjadi sasaran belajar, mencari informasi sehubungan dengan permasalahan yang dihadapi melalui berbagai sumber, dan sumber informasi yang diperoleh relevan. Adapun indicator mengolah informasi tercapai apabila informasi yang didapat diidentifikasi dan diklasifikasikan berdasrkan peristiwa, menafsirkan fakta dan peristiwa yang telah di klasifikasikan, serta membuat prediksi berdasarkan hasil pengolahan informasi. Sedangkan indicator pengambilan 
keputusan tercapai apabila siswa mampu mengidentifikasi potensi resiko, mengidentifikasi informasi yang tersedia, dan menentukan pilihan keputusan secara bijak. Pumphrey, J. \& Slater, J (Pumphrey, J. \& Slater, 2002).

Hasil analisis keterampilan thinking skills siswa menunjukkan bahwa kompetensi tertinggi pada keterampilan thinking skills yakni menggali/ mengumpulkan informasi. Hal tersebut dikarenakan kompetensi ini telah dilatihkan dari tahap awal pembelajaran. Sejalan dengan Permendikbud Nomor 81a Tahun 2013 bahwa aktivitas mengumpulkan informasi dilakukan melalui eksperimen, membaca sumber lain selain buku teks, mengamati objek/ kejadian/ aktivitas wawancara dengan nara sumber dan sebagainya. Sehingga dari kompetensi menggali informasi diharapkan dapat mengembangkan sikap teliti, jujur, sopan, menghargai pendapat orang lain, kemampuan berkomunikasi, menerapkan kemampuan mengumpulkan informasi melalui berbagai cara yang dipelajari, mengembangkan kebiasaan belajar dan belajar sepanjang hayat.

\section{Academic Skills}

Keterampilan academic skills yang dinilai meliputi 1) merumuskan masalah, 2) merumuskan hipotesis, 3) menentukan variabel, 4) membuat rancangan percobaan, 5) menyajikan data dalam tabel, 6) menganalisis data, dan 7) membuat kesimpulan. Penilaian academic skills dilakukan melalui 2 cara yakni melalui pengamatan dan tes hasil belajar. Pengamatan dilakukan selama 3 kali pertemuan. Pengamatan dilakukan oleh 2 orang pengamat. Hasil analisis ketercapaian aspek kemampuan academic skills menggunakan lembar pengamatan selama 3 hari diperoleh sebagai berikut:

\begin{tabular}{|l|l|c|c|c|c|}
\hline \multirow{2}{*}{ No } & \multirow{2}{*}{ Kompetensi } & \multicolumn{2}{|c|}{ Pre Test } & \multicolumn{2}{c|}{ Post Test } \\
\cline { 3 - 6 } & \multicolumn{1}{c|}{$\begin{array}{c}\% \\
\text { Ketercapaian }\end{array}$} & Keterangan & $\begin{array}{c}\% \\
\text { Ketercapaian }\end{array}$ & Keterangan \\
\hline 1 & Merumuskan masalah & 36 & $\mathrm{TT}$ & 87 & $\mathrm{~T}$ \\
\hline 2 & Merumuskan hipotesis & 33 & $\mathrm{TT}$ & 78 & $\mathrm{~T}$ \\
\hline 3 & Menentukan Variabel & 44 & $\mathrm{TT}$ & 79 & $\mathrm{~T}$ \\
\hline 4 & $\begin{array}{l}\text { Membuat rancangan } \\
\text { Percobaan }\end{array}$ & 30 & $\mathrm{TT}$ & 82 & $\mathrm{~T}$ \\
\hline 5 & $\begin{array}{l}\text { Menyajikan data } \\
\text { dalam tabel }\end{array}$ & 33 & $\mathrm{TT}$ & 84 & $\mathrm{~T}$ \\
\hline 6 & Menganalisis data & 40 & $\mathrm{TT}$ & 79 & $\mathrm{~T}$ \\
\hline 7 & Membuat kesimpulan & 49 & $\mathrm{TT}$ & 86 & $\mathrm{~T}$ \\
\hline
\end{tabular}

Tabel 1.1 Ketercapaian kompetensi Academic Skills 
Sedangkan data tes hasil belajar pretest dan posttest kemampuan academic skills secara ringkas disajikan pada gambar 1.3.

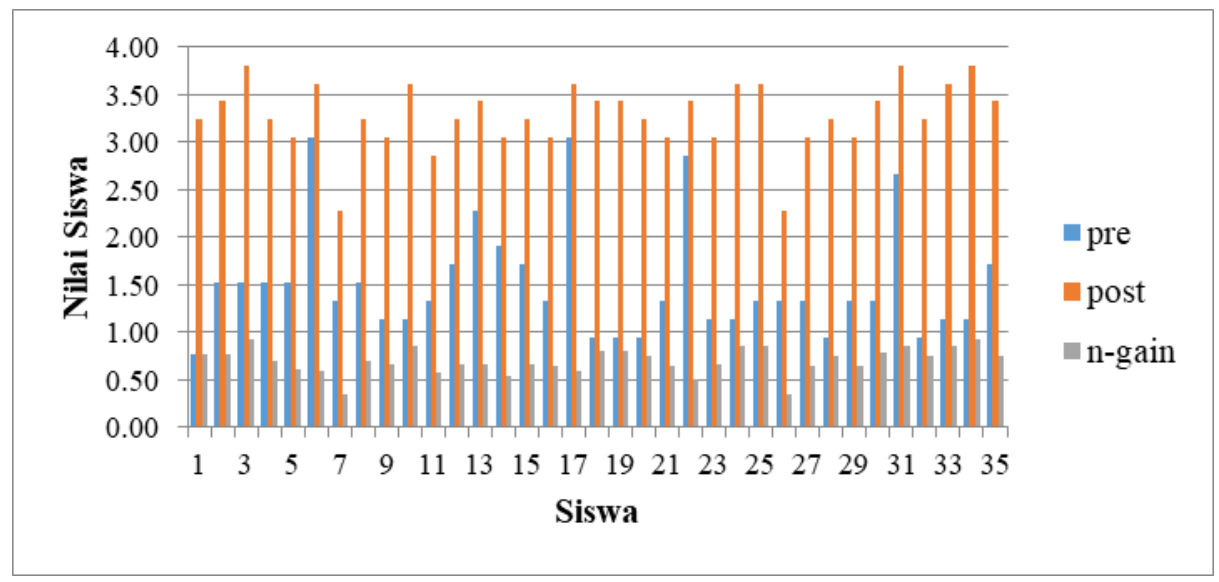

Gambar 1.3 Hasil Belajar Pretest Dan Posttest Kemampuan Academic Skills

Setiap kompetensi academic skills dikatakan tercapai apabila skornya mencapai indicator penilaiannya. Adapun indicator penilaian dari setiap kompetensi academic skills antara lain:

a. Merumuskan masalah

Kompetensi merumuskan masalah dikatakan tercapai apabila Rumusan masalah yang dibuat sesuai dengan fenomena yang diberikan, Rumusan masalah yang dibuat menginterpretasikan percobaan yang akan dilakukan, dan Rumusan masalah yang dibuat singkat dan jelas.

b. Merumuskan hipotesis

Kompetensi merumuskan hipotesis dikatakan tercapai apabila Pernyataan yang dibuat sederhana dan berdasarkan pengamatan, Hipotesis bisa digunakan dalam merancang percobaan, dan Hipotesis dapat berfungsi sebagai dasar melakukan percobaan.

c. Menentukan variable

Kompetensi menentukan variabel dikatakan tercapai apabila Variabel yang dibuat sesuai dengan hipotesis, Variabel yang dibuat singkat dan jelas, Variabel dapat berfungsi sebagai dasar melakukan percobaan.

d. Membuat rancangan percobaan

Kompetensi Membuat rancangan percobaan dikatakan tercapai apabila Rancangan percobaan yang dibuat mengujikan hipotesis, Rancangan percobaan yang dibuat dapat mengidentifikasi variabel respon, Rancangan percobaan yang dibuat jelas dan sesuai urutan. 
e. Menyajikan hasil pengamatan dalam bentuk tabel

Indikator tercapainya kompetensi menyajikan hasil pengamatan dalam bentuk tabel yakni Tabel yang dibuat mencakup data yang sesuai, Data untuk variabel manipulasi dan variabel respon dinyatakan secara jelas, Informasi dalam tabel terorganisasi secara tepat.

f. Menganalisis data

Indicator tercapainya kompetensi menganalisis data antara lain Analisis yang dibuat berdasarkan data hasil pengamatan, Analisis data yang dibuat merupakan hasil pemikiran sendiri, Analisis yang dibuat singkat dan jelas

g. Membuat kesimpulan

Indicator tercapainya kompetensi membuat kesimpulan yaitu Kesimpulan dibuat berdasarkan data hasil pengamatan/ percobaan, Kesimpulan yang dibuat dapat menjawab pertanyaan penelitian, Menggunakan kalimat yang singkat dan jelas

Menurut Samani academic skills dibutuhkan manusia untuk menjalankan peran manusia sebagai bagian dari lingkungan (Samani, 2002). Manusia sebagai khalifah di muka bumi dan diamanahi oleh Sang Pencipta untuk memelihara dan memanfaatkan alam lingkungan, demi kemaslahatan untuk manusia. Akhir-akhir ini kerusakankerusakan lingkungan sering terjadi di mana-mana. Hal ini dikarenakan oleh ulah manusia yang kurang bertanggung jawab dan kurangnya kesadaran akan pentingnya menjaga lingkungan. Gambaran tersebut menunjukkan bahwa untuk dapat memelihara dan memanfaatkan lingkungan alam dengan arif dan kreatif, diperlukan kecakapan akademik yang terkait dalam bidang itu (academic skills) (Samani, 2002).

\section{Social Skills}

Penilaian kemampuan social skills dinilai berdasarkan hasil pengamatan. Nilai kemampuan social skills siswa meliputi (1) Mengajukan pertanyaan, (2) Menjawab pertanyaan, (3) Mengemukakan pendapat, (4) Menanggapi pendapat, (5) presentasi lisan. Skor rata-rata dari kompetensi kecakapan sosial (Social skills) dapat disajikan pada diagram berikut: 


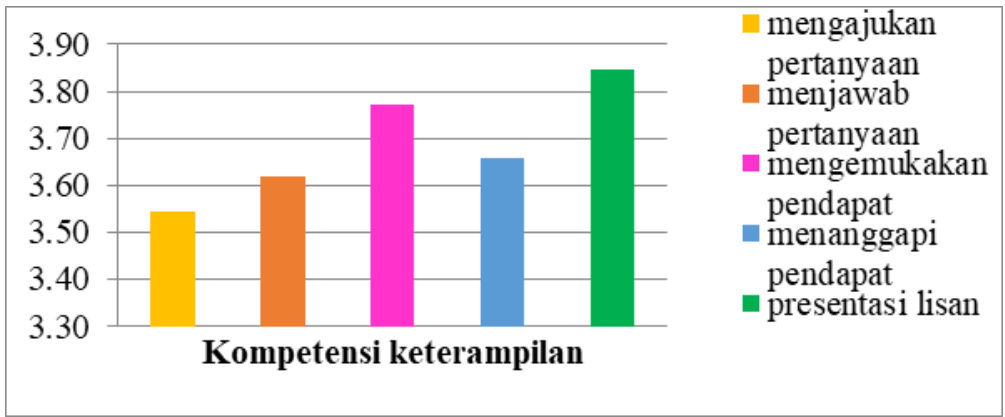

Gambar 1.4. Diagram Nilai Kemampuan (Social Skills)

Kecakapan sosial terdiri dari: kecakapan berkomunikasi (communication skills) dan kecakapan bekerjasama (collaboration skills). Kecakapan berkomunikasi dapat dilakukan baik secara lisan maupun tulisan. Penelitian ini akan melatihkan kecakapan komunikasi secara lisan. Kecakapan berkomunikasi secara lisan dapat dilatihkan melalui proses pembelajaran. Kecakapan berkomunikasi dapat dilakukan baik secara lisan maupun tulisan.

Sebagai makhluk sosial yang hidup dalam masyarakat tempat tinggal maupun tempat kerja, peserta didik sangat memerlukan kecakapan berkomunikasi baik secara lisan maupun tulisan. Dalam realitasnya, komunikasi lisan tidak mudah dilakukan. Sering kali orang tidak dapat menerima pendapat lawan bicaranya, bukan karena isi atau gagasannya tetapi karena cara penyampaiannya yang kurang berkenan. Dalam hal ini diperlukan kemampuan bagaimana memilih kata dan cara menyampaikan agar mudah dimengerti oleh lawan bicaranya

Adapun indicator tercapainya kemampuan social skills (berkomunikasi) peserta didik antara lain:

\begin{tabular}{|l|l|}
\hline \multicolumn{1}{|c|}{ Kompetensi } & \multicolumn{1}{|c|}{ Indikator } \\
\hline Mengajukan pertanyaan & $\begin{array}{l}\text { 1. } \begin{array}{l}\text { Pertanyaan yang diajukan relevan dengan topik yang } \\
\text { dibahas } \\
\text { 2. Pertanyaan yang diajukan merupakan pertanyaan } \\
\text { yang dibuat sendiri }\end{array} \\
\text { 3. Kualitas vokal seperti volume dan artikulasi jelas dan } \\
\text { dapat dipahami oleh pendengar }\end{array}$ \\
\hline Menjawab pertanyaan & $\begin{array}{l}\text { 1. Jawaban yang diberikan singkat dan jelas } \\
\text { Jawaban yang diberikan relevan dengan pertanyaan } \\
\text { yang diajukan } \\
\text { Kualitas vokal seperti volume dan artikulasi jelas dan } \\
\text { dapat dipahami oleh pendengar }\end{array}$ \\
\hline
\end{tabular}




\begin{tabular}{|l|l|}
\hline \multicolumn{1}{|c|}{ Kompetensi } & \multicolumn{1}{|c|}{ Indikator } \\
\hline $\begin{array}{l}\text { Mengemukakan } \\
\text { pendapat }\end{array}$ & $\begin{array}{l}\text { 1. } \begin{array}{l}\text { Ide yang disampaikan relevan dengan topik yang } \\
\text { dibahas }\end{array} \\
\text { 2. } \begin{array}{l}\text { Ide yang disampaikan merupakan hasil pemikiran } \\
\text { sendiri }\end{array}\end{array}$ \\
\hline
\end{tabular}

Tabel 1.2 Kompetensi dan Indikator Kecakapan Komunikasi

Menurut Samani, bahwa keberhasilan seseorang tidak ditentukan oleh kemampuan kognitifnya atau penguasaan materi saja, tetapi lebih ditentukan oleh kecakapan hidup yang dimilikinya, salah satunya yakni kecakapan social (Samani, 2002). Hasil analisis keterampilan social skills siswa menunjukkan bahwa kompetensi terendah pada keterampilan social skills yakni mengajukan pertanyaan. Rendahnya kemauan siswa untuk bertanya disebabkan adanya kekhawatiran akan dianggap bodoh apabila terlalu sering bertanya. Perasaan khawatir tidak diterima oleh teman dapat membawa masalah emosi yang serius karena pada remaja kebutuhan untuk diterima di kelompoknya sangatlah penting ${ }^{1}$.

\section{Penutup}

Peningkatan life skills melalui pendekatan scientific yaitu thinking skills, academic sklills dan social skills sebelum diterapkan pembelajaran dengan pendekatan scientific terlihat sangat signifikan, dimana antara skor pretest dan post test mengalami kenaikan. Sehingga dapat dikatakan bahawa pendekatan scientific mampu meningkatkan life skills peserta didik.

\section{Daftar Rujukan}

Anwar. (2006). Pendidikan Kecakapan Hidup Konsep dan Aplikasi. Bandung: Alfabeta.

Education, T. B. B. (2002). Konsep Pendidikan Kecakapan Hidup. Jakarta: Depdiknas.

Foong May, Y. (2014). Science Students And The Social Siences. Higher Education Research and Development, 33(5).

Kemendikbud. (2013). Pendekatan Scientific dalam Kurikulum 2013. Jakarta: Kementrian Pendidikan dan Kebudayaan.

Kemp, J. E., M. G. R., and Ross, S. M. (1994). Designing Effective Instruction,. United States of America: MacMillan College Publishing Company.

Pumphrey, J. \& Slater, J. (2002). An Assessment of Generic Skill Needs (D. for E. and Skills, Ed.). Notingham.

\footnotetext{
${ }^{1}$ Oemar Hamalik, Proses Belajar Mengajar. (Jakarta: Bumi Antariksa, 2008), 258.
} 
Samani, M. (2002). Menggagas Pendidikan Bermakna Integrasi Life Skills-KBK-CTL$M B S$. Surabaya: SIC.

Timur, L. J. (2005). Efektifitas Pendidikan Kecakapan Hidup Dalam Upaya Pemberdayaan Masyarakat Miskin. Perpustakaan UIN Sunan Ampel, 4(2).

Tuckman, B. . (1986). Conducting Educational Research Second Edition. USA: Harcourt Brace Jovanovich, Publisher. 